
СТРИЖНЕВИХ СУМІШЕЙ

\author{
Solonenko L.I., Bilyi O.P., Uzlov K.I.
}

\title{
FUNCTIONAL DEPENDENCIES BETWEEN SAMPLE PROPERTIES FROM STRUCTURED MOLDING AND CORE MIXTURES
}

\begin{abstract}
Робота присвячена питанням встановлення ффункціональних залежностей між параметрами структурованих фрормувальних і стрижневих сумішей, які визначають на зразках за стандартними і загальноприйнятими методиками. Мета роботи - підвищення точності прогнозування властивостей структурованих формувальних і стрижневих сумішей для одноразових ливарних форм. Для встановлення загальної структури передбачуваних залежностей використовували л-теорему аналізу розмірностей. За результатами теоретичних досліджень вперше встановлено функціональні залежності між обсипальністю, крихкістю, міцністю, роботою вибивання виливків з форм і стрижнів з виливків та рядом параметрів і властивостей структурованих фрормувальних і стрижневих сумішей.Використання цих залежностей дозволить підвищити точність аналізу $i$ прогнозування рівнів ряду властивостей, а також прискорить процес оптимізації складів формувальних $i$ стрижневих сумішей при їх використанні в ливарних цехах. В кінцевому рахунку, підвищення точності прогнозування властивостей структурованих сумішей спричинить за собою підвищення якості виливків $і$ зниження рівня браку литих деталей.Відзначається, що в першому наближенні оцінку вибивання сумішей можна проводити за величиною їх залишкової міцності.

Ключові слова: обсипальність, міцність, крихкість, робота вибивання, виливок, стрижнева суміш, фрормувальна суміш

Article is devoted to functional dependencies between the parameters of structured molding and core mixtures establishment, which are determined on samples using standard and generally accepted methods. The aim of the work is properties of structured molding and core mixtures for disposable casting molds predicting accuracy improvement.To establish the general structure of proposed dependences, dimensional analysis $\pi$-theorem has been used. According to theoretical studies results, functional dependencies between flaking, brittleness, strength, castings from castings molds and cores knockout work and number of parameters and properties of structured molding and core mixtures were established for the first time. These dependencies implementation will improve analysis and prediction of number of properties levels accuracy, as well as accelerate compositions of molding and core mixtures optimizing process when used in foundries. Ultimately, accuracy increasing in prediction of structured mixtures properties will entail castings quality improvement and level of cast parts nonconformance decreasing. It has been noted that, in first approximation, it's permissible to estimate mixtures knockout ability according to their residual strength values.

Keywords: crumbling, strength, brittleness, work of knocking out, casting, core mixture, molding sand
\end{abstract}

Вступ. В даний час комплексну оцінку структурованих формувальних і стрижневих сумішей, як правило, проводять виходячи з величин їх показників:

газодинамічних (газопроникність, газотвірна здатність);

технологічних (обсипальність, податливість, плинність, стиранність, ремонтопридатність, прилипаємість, придатність до регенерації, гігроскопічність, схильність до утворення ужимін, вибиваємість і т.д.);

теплофізичних (питома теплоємність, теплопровідність, температуропровідність, теплоакумулююча здатність);

фрізико-хімічних (вологість, уявна щільність, фрракційний склад, фоорма частинок зернистого вогнетривкого матеріалу суміші, модуль Юнга, хімічна активність у ставленні до залитого ме- талу або сплаву тощо), у тому числі, механічних (межа міцності при стиску, розтяганні, статичному вигині, твердість тощо).

Багатофакторність, нерівнозначність і різновекторність впливу умов виробництва на якість виливків - характерні риси будь-якої ливарної технології. Ці особливості призводять до постійного «дрейфу» в часі оптимуму поєднання властивостей ливарних форм і стрижнів, співвідношень значущості фракторів і технологічної вагомості параметрів в процесі формування якості виливків і стабільності технології їх виробництва. 3 цього, успішне і швидке рішення ливарних завдань пов'язано не тільки зі знанням значень перерахованих вище властивостей і параметрів, але i їх взаємного впливу, зі знанням закономірностей їх комплексної зміни при виникненні технологічних збурень в процесі виробництва лиття.
Солоненко Людмила Ігорівна - к.т.н, ОНПУ., ORCID 0000-0003-2092-8044

Білий Олександр Петрович - НМетАУ

ORCID 0000-0003-1234-5404

Узлов Костянтин Іванович - д.т.н., професор НМетАУ

ORCID 0000-0003-0744-9890
Solonenko Lyudmila - CTS, ONPU

Bilyi Oleksandr - NMetAU

Uzlov Konstantin - d.t.s. Professor NMetAU 
Аналіз літературних даних та постановка проблеми. Дослідженням властивостей ливарних форм і стрижнів присвячена велика кількість робіт [1...7 та ін.], а методики визначення та розрахунку ряду цих властивостей викладені у відповідній нормативній документації (стандартах). До числа найбільш важливих параметрів сумішей для ливарних форм і стрижнів відносять: обсипальність, крихкість, газопроникність, міцність і вибиваємість - робота вибивання, яку витрачають на вибивання виливків з форм і стрижнів з виливків.

Обсипальність (Оc) - показник поверхневої міцності або здатності поверхні виробу (форми, стрижня, зразка) протистояти руйнуванню при стиранні. Обсипальність визначають відповідно до ГОСТ 23409.9, як відносна зміна маси зразка циліндричної форми $(\varnothing 50 \times 50$ мм) із структурованої суміші після його стирання протягом 1 хв в сітчастому барабані. В цьому випадку, справжня розмірність абсолютної величини обсипальності -

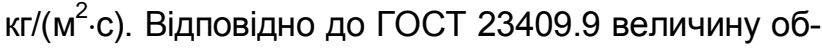
сипальності прийнято виражати у відсотках, як відносна зміна маси зразка до і після його випробувань. Обсипальність залежить від міцності структурованої суміші, природи і кількості сполучного матеріалу в суміші, уявної щільності і т.д. та не $є$ постійною в часі. Тобто, при зберіганні обсипальність форм і стрижнів може змінюватися (як правило - збільшуватися). За інших рівних умов на ве- личину обсипальності істотно впливає питома щільність застосовуваного в суміші зернистого вогнетривкого матеріалу, форма його зерен, структура суміші і т.п. [8, 9].

Крихкість (Хр) - один з показників технологічності структурованих сумішей. В даний час крихкість формувальних і стрижневих сумішей оцінюють по величині симплекса [10]:

$$
X p=\frac{\sigma_{C \nVdash}}{\sigma_{B}},
$$

де $\sigma_{C ж}, \sigma_{B}-$ межа міцності структурованої суміші при стисненні і розтягуванні відповідно.

При цьому структурована суміш тим більш технологічна, тим пластичніше, чим більше величина $\mathrm{Xp}$.

Робота вибивання (A) - це робота, яку необхідно затратити на вибивання виливків з форм і/або стрижнів з виливків.

В даний час в якості критерію оцінки вибивання суміші не деякі дослідники використовують значення величини роботи, витраченої на руйнування зразка суміші $\varnothing 50 \times 30$ мм [10]. Перед випробуваннями «сирі» або термічно оброблені зразки з випробуваної структурованої суміші з натягом укладають в сталеву гільзу відповідно до схеми на рис. 1.

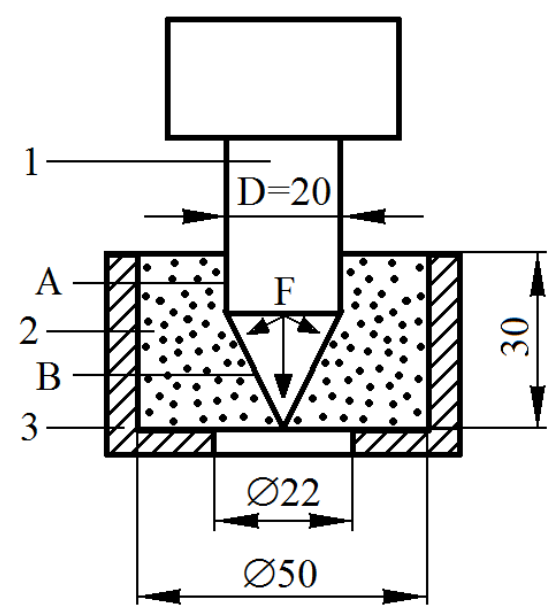

Після цього, у верхній поверхні зразка встановлюють сталевий бойок і на лабораторному копрі б'ють по бойку до тих пір, поки він не проникне в зразок на глибину 30 мм. Роботу (A), витрачену на пробивання зразка на зазначену глибину, розраховують за формулою, Дж (кг· $\left.\mathrm{m}^{2} / \mathrm{c}^{2}\right)$ :

$$
A=n \cdot G \cdot h \text {, }
$$

де $\mathrm{n}$ - число ударів по бойку до пробивання зразка на глибину 30 мм; G - маса падаючого на бойок вантажу в копрі; $\mathrm{h}$ - висота падіння вантажу на копрі.

Ряд авторів як критерій оцінки вибивання суміші використовують число ударів копра по бойку [11, 12] або величину межі міцності при стисненні суміші після її попереднього нагрівання до певної температури (величину залишкової міцності) $[10,13,14]$ і т.д.

У прийнятій схемі випробувань (див. рис. 1) руйнування матеріалу зразка відбувається в результаті розколювання і роздавлювання структурованої суміші. Виходячи з цього, кількість енергії (роботи), витраченої на вибивання, можна розраховувати за фрормулами, складеними на основі гіпотези Ріттенгера (гіпотеза поверхонь) або гіпотези В.Л. Кирпичова (гіпотеза об'ємів).

Відповідно до гіпотези Ріттенгера, робота, витрачена при подрібненні (руйнуванні) тіла, пропорційна площі поверхні, що знову утворилася, або ступені подрібнення тіла. Тобто, відповідно до гіпотези Ріттінгера (гіпотези поверхонь): 


$$
A_{R}=z_{R} \cdot S
$$

де $z_{R}$ - коефіцієнт пропорційності; $S$ - площа поверхонь, що виникли в результаті руйнування тіла.

Відповідно до гіпотези В.Л. Кирпичова (гіпотеза об'ємів), енергія, необхідна для однакової зміни форми геометрично подібних тіл, пропорційно об'ємам або масам цих же тіл. Тобто, відповідно до гіпотези об'ємів, виходячи із закону Гука, роботу руйнування (дроблення) тіла розраховують за формулою:

$$
A_{K}=\frac{\sigma_{C Ж}^{2} \cdot V}{2 E},
$$

де $\sigma_{\text {сж }}$ - межа міцності на стиск матеріалу тіла; E - модуль пружності першого роду матеріалу тіла; V - об'єм тіла.

У гіпотезі В.Л. Кирпичова враховані витрати енергії насамперед на пружну, а потім на пластичну деформацію, але не враховані витрати енергії на виникнення в тілі поверхонь руйнування, на подолання сил зовнішнього і внутрішнього тертя, на втрати енергії, викликаними тепловими явищами і т.п. 3 цього випливає, що гіпотеза В.Л. Кирпичова застосовна при дробленні, а гіпотеза Ріттінгера при розломі (тонкому подрібненні) тіла $[15,16]$.

Будь-яке подрібнення реального тіла представляє сукупність процесів стирання, дроблення, розламування і т.д., що одночасно проходять, але виражених в різному ступені і мінливих в часі. Виходячи з цього П.А. Ребиндер, прийнявши, що енергія, яка витрачається на подрібнення матеріалу, є сумою енергій, витрачених як на деформацію матеріалу, що подрібнює тіло, так і на утворення нових поверхонь, роботу подрібнення розраховує за формулою:

$$
A=A_{R}+A_{K} .
$$

Виходячи 3 описаної вище методики визначення роботи, витраченої на вибивання циліндричного зразка з обойми, його розмірів, форми і розмірів бойка, формулу (5) слід доповнити наступними складовими (див. рис. 1):

- робота $\left(\mathrm{A}_{\mathrm{A}}\right)$, витрачена на подолання сили тертя $\left(\mathrm{F}_{\mathrm{TP}}\right)$ на циліндричній поверхні бойка $(\mathrm{A})$ при його русі в зразку:

$$
A_{A}=\pi \cdot D \cdot l_{A} \cdot \mu \cdot\left(\sigma_{C ж}+\sigma\right),
$$

де $\mathrm{I}_{\mathrm{A}}$ - довжина циліндричної частини бойка, що заглиблена в матеріал зразка; $\mu$ - коефріцієнт тертя; $\sigma$ - стискаючі напруги в зразку, викликані натягом обойми при посадці в неї зразка (для реального виливка - лінійною усадкою виливка при його охолодженні); $\pi=3,14$;

- робота $\left(A_{B}\right)$, витрачена при проходженні в суміші конічної частини бойка (B) шляху протяжністю I:

$$
A_{B}=\frac{\pi \cdot D^{2}}{4} \cdot\left(\sigma_{\text {ЭФ }}+\sigma\right) \cdot l \cdot \cos \alpha,
$$

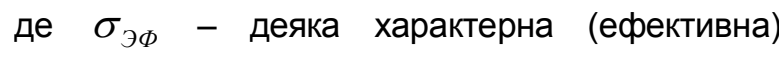

напруга; cos $\alpha$ - косинус кута між вектором прикладеної сили і вектором переміщення поверхні;

- робота $\left(A_{D}\right)$ сили пружності при переході матеріалу бойка 3 недеформованого стану в деформований при ударі по бойку:

$$
A_{D}=\frac{k \cdot \Delta l_{2}}{2},
$$

де $\mathrm{k}$ - жорсткість матеріалу бойка; $\Delta /$ абсолютний стиск матеріалу бойка при ударі по ньому.

У цьому випадку формула (5) з урахуванням (6)...(8) матиме вигляд:

$$
A=A_{R}+A_{K}+A_{A}+A_{B}+A_{D} .
$$

3 аналізу формули (9) випливає, що робота вибивання зразка за затвердженою методикою залежна від значного числа змінних фракторів і здебільшого може бути використана для якісної оцінки впливу того чи іншого параметра на вибивання виливка з форми і стрижня з виливка.

Межа міцності структурованої суміші при стисненні (бсж) - показник її здатності зберігати цілісність виробу (форми, стрижня, зразка) при впливі на нього зовнішнього стискаючого навантаження. Як правило для визначення величини $\sigma_{\text {сж }}$ використовують зразки циліндричної фрорми з структурованої суміші з розмірами від $\varnothing 20 \times 20$ до

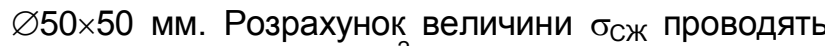

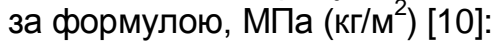

$$
\sigma_{C \nVdash}=\frac{P}{F},
$$

де $\mathrm{P}$ - навантаження при якому сталося руйнування зразка, що стискається; F - площа поперечного перерізу зразка.

За даними [17...19] межа міцності структурованої суміші при стисненні залежить від багатьох факторів в числі яких - уявна щільність структурованої суміші, масова частка сполучного матеріалу в суміші, спосіб і умови затвердіння сполучного матеріалу в суміші і т.п. Проте, формула (10) дані залежності і закономірності не відображає.

Газопроникність (К) - показник здатності структурованої суміші пропускати через себе повітря. Газопроникність структурованої суміші розраховують за результатами виконання методики відповідно до ГОСТ 23409.6 за формулою:

$$
K=\frac{V \cdot h}{F \cdot P \cdot \tau},
$$

де - V об'єм газу (повітря), що пройшов через зразок за час випробувань $\tau\left(\mathrm{V}=2000 \mathrm{~cm}^{3}\right), \mathrm{cm}^{3} ; \mathrm{h}-$ висота (довжина) зразка, см; F - площа поперечного перерізу зразка, см²; Р - тиск повітря під зразком під час проведення його випробувань, Па (г/см² або сантиметрів водного стовпа); $\tau$ - тривалість проходження $2000 \mathrm{~cm}^{2}$ газу (повітря) через зразок, хв. 
Розмірність газопроникності - $\mathrm{cm}^{4} /($ г.хв) або умовні одиниці.

Газопроникність залежить від величини уявної щільності матеріалу зразка, розмірів і форми зерен його зернистого вогнетривкого матеріалу і т.д.

Удавана щільність - показник маси одиниці об'єму структурованої суміші. Величина даного параметра залежить від істинної щільності матеріалів, що входять до складу структурованої суміші, їх кількості та її порозності. Розмірність уявної щіль-

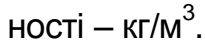

Аналіз літературних даних по визначенню і розрахунку зазначених параметрів показує відсутність системного підходу в процесі вивчення їх взаємодії і взаємного впливу. Тобто в характеристиках сумішей дані параметри і властивості розглядають самостійними і незалежними один від одного. Такий підхід знижує вірогідність прогнозу, а в ряді випадків робить неможливим проведення комплексного аналізу та прогнозування зміни властивостей структурованих сумішей при виникненні значних збурень в технологічному процесі.

Мета досліджень - підвищити точність прогнозування обсипальності, крихкості, міцності і вибивання структурованих сумішей.

Завдання досліджень - встановити функціональні залежності між обсипальністю, крихкістю, міцністю, роботою вибивання виливків з форм і стрижнів з виливків і рядом параметрів і властивостей структурованих формувальних і стрижневих сумішей, які визначають на зразках за стандартними і загальноприйнятими методиками.

Методи дослідження. Для встановлення загальної структури передбачуваної залежності між обраними параметрами, заснованої тільки на інваріантності фізичної залежності при зміні масштабів одиниць, використовували $\pi$-теорему аналізу розмірностей. 3 цією метою припустили, що між $\mathrm{n}$ даних фрізичних величин (відібраних параметрів) існує якась залежність, у якій вид постійний навіть при зміні масштабів одиниць в деякому класі систем одиниць. Тобто, вона еквівалентна залежності між меншим числом $\mathrm{p}=\mathrm{n}-\mathrm{k}$ безрозмірних величин,
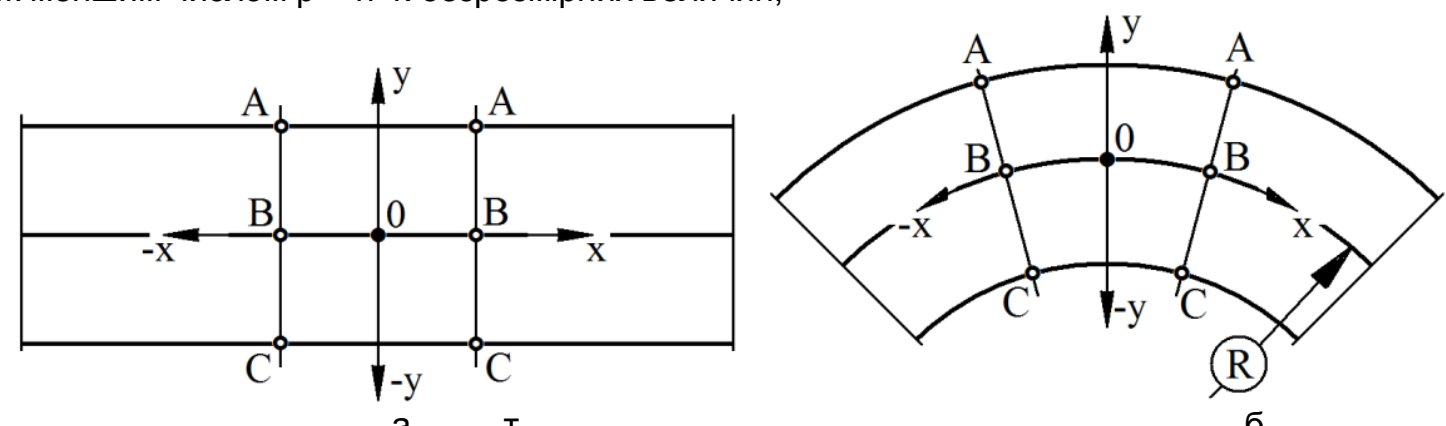

Рисунок 3 - Схема балки до (а) і після (б) вигину де k - найбільше число величин з незалежними розмірностями серед вихідних $\mathrm{n}$ величин.

Результати дослідження. Стосовно до показника обсипальності в число змінних передбачуваної залежності для використання методу аналізу розмірностей включили: К - газопроникність зразка (характеристика структури затверділої суміші), $\mathrm{m}^{4} /(\kappa г \cdot c) ; \sigma_{\text {сж }}$ - межа міцності зразка на стиск (характеристика природи матеріалів, складу і структури затверділої суміші), кг/м²; $\rho$ - уявна щільність затверділої суміші (характеристика складу і структури затверділої суміші), кг/м³; I - довжина циліндричного зразка (характеристика геометричних розмірів зразка суміші), м.

В результаті розрахунку отримали наступну залежність:

$$
O c=z_{0} \cdot \rho^{3} \cdot l \cdot \frac{K}{\sigma_{C Ж}},
$$

де $\mathrm{z}_{0}$ - безрозмірний поправочний коефіцієнт.

Крихкість структурованої суміші оцінювали за величиною стріли прогину $(\varepsilon)$ зразка балочного типу, встановленого на опори на певній відстані одна вид одної (I), в момент його руйнування під дією навантаження (P), яке додається до зразка за триточковою схемою, що схематично надано на рис. 2.

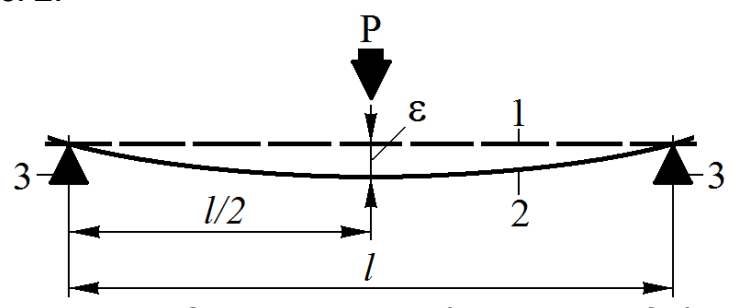

Рисунок 2 - Схема прогину балки: 1 - вид балки (зразка) до дослідження; 2 - вид балки в момент руйнування; 3 - опора зразка

В умовах такої схеми навантаження, матеріал балки одночасно відчуває як стискаючі, так і розтягуючі напруги, що випливає з схем балки до і після ії̈ вигину (деформації), представлених на рис. 3.
При цій схемі навантаження деформація $\varepsilon$ в кожній точці балки буде пропорційна координаті «у», яку в даному випадку відраховують від нейтральної (центральної) лінії (осі $x-x)$. Це означає, що в результаті деформації відстань між точками А-А збільшується, між точками С-С - зменшується, а відстань між точками В-В на нейтральній лінії залишається незмінним. Тобто, зі схеми на рис. 2, б випливає, що: 


$$
\varepsilon=\frac{y}{R}
$$
ня.

де R - радіус кривизни бруса після викривлен-

Відповідно, величина нормальної напруги (б) в даному перетині балки також залежить від координати «у» і визначається із закону Гука:

$$
\sigma=\varepsilon \cdot E
$$

де Е - модуль пружності матеріалу балки.

Для відносно малих прогинів балки, що характерно для структурованих сумішей, прийнявши уздовж осі 0-х постійними величини модуля пружності і момент інерції (I), фрорму балки описують лінійним диференціальним рівнянням 4-го порядку (диференціальним рівнянням Ейлера-Бернуллі):

$$
E \cdot l \cdot \frac{d^{4} x}{d x^{4}}=P .
$$

Будь-який варіант рішення рівняння ЕйлераБернуллі (15) призводить до залежності стріли прогину лише від відстані між опорами балки (I), а також параметрами, що входять в формулу (15). Тобто формула (15), як і формула (13) не враховує особливості будови структурованих сумішей, де розміри і об'єм пор можуть бути порівняні з розмірами і об'ємом балки, рівня напруженого стану структурованої суміші і т.п.

У зв'язку з цим, як і в описаних вище випадках, для визначення закономірностей впливу основних параметрів структурованої суміші на граничнодопустиму стрілу прогину зразка балочного типу використовували метод аналізу розмірностей. У числі змінних ймовірної залежності: К - газопроникність зразка (характеристика структури затверділої суміші), м/(кг·с); Ос - обсипальність (характеристика поверхневої міцності матеріалу стрижня або форми), кг/(м².c); $\rho$ - уявна щільність затверділої суміші (характеристика складу і структури затверділої суміші), кг/м³; I - відстань між опорами зразка (характеристика геометричних розмірів зразка суміші), м.

В результаті розрахунку отримали наступну залежність:

$$
\varepsilon=z_{\varepsilon} \cdot l \cdot \rho^{2} \cdot \frac{K}{O c},
$$

де $z_{\varepsilon}$ - безрозмірний поправочний коефіцієнт.

Якщо праву і ліву частину фрормули (16) розділити на відстань між опорами (I), то отримаємо формулу для розрахунку відносної граничноприпустимої величини стріли прогину:

$$
\Delta_{\varepsilon}=\frac{\varepsilon}{l}=z_{\varepsilon}^{*} \cdot \rho^{2} \cdot \frac{K}{O c},
$$

де $z_{\varepsilon}^{*}$ - безрозмірний поправочний коефіцієнт.

Якщо (12) підставити в (17), то отримаємо такий вираз для розрахунку абсолютної величини стріли прогину балки із структурованої суміші:

$$
\varepsilon=\frac{z_{\varepsilon}^{*}}{z_{0}} \cdot \frac{\sigma_{C \nVdash}}{\rho} .
$$

Стосовно до показника вибивання (робота вибивання) в якості змінних використовували такі параметри зразка структурованої суміші: $\sigma_{C ж}-$ межа

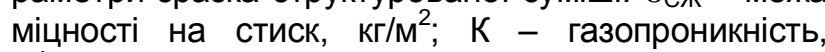
$\mathrm{m}^{4} /(\kappa г \cdot c) ; ~ I-$ довжина зразка, м.

В результаті розрахунку отримали наступну залежність:

$$
A=z_{A} \cdot K^{2} \cdot \sigma_{C Ж}^{2} \cdot l \cdot \rho=z_{A} \cdot K^{2} \cdot \sigma_{C Ж}^{3},
$$

де $z_{A}-$ безрозмірний поправочний коефіцієнт.

Для обчислення межі міцності структурованої суміші при стисненні в якості змінних використовували такі параметри зразка структурованої суміші: $\rho, \rho_{\mathrm{CB}}$ - уявна щільність структурованої суміші дійсна щільність затверділого сполучного матері-

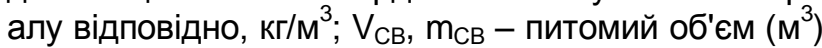
і питома маса (кг) затверділого сполучного матеріалу в суміші відповідно; $\mathrm{S}_{п}$ - питома площа поверхні зернистої складової структурованої суміші, м².

В результаті розрахунку отримали наступну залежність:

$$
\sigma_{C Ж}=z_{\sigma} \cdot \rho \cdot \frac{V_{C B}}{S_{\Pi}}=z_{\sigma} \cdot \frac{\rho}{\rho_{C B}} \cdot \frac{m_{C B}}{S_{\Pi}},
$$

де $z_{\sigma}$ - безрозмірний поправочний коефіцієнт.

Якщо розглянуті властивості структурованих сумішей змінюються в часі, наприклад, під час зберігання форм і стрижнів до заливки, то ці зміни можливо врахувати шляхом зведення в відповідну ступінь правих частин фрормул (12), (18) ... (20) та їх множення на показник часу $(\tau)$. Величину показників ступенів в такому випадку розраховують за експериментальними даними. Тобто:

$$
\begin{gathered}
O c=z_{0} \cdot \tau^{n 1} \cdot\left(\rho^{3} \cdot l \cdot \frac{K}{\sigma_{C K}}\right)^{n}, \\
\varepsilon=\frac{z_{\varepsilon}^{*}}{z_{0}} \cdot \tau^{f 1} \cdot\left(\frac{\sigma_{C}}{\rho}\right)^{f}, \\
A=z_{A} \cdot \tau^{j 1} \cdot\left(K^{2} \cdot \sigma_{C \%}^{2} \cdot l \cdot \rho\right)^{j}=z_{A} \cdot \tau^{j 1} \cdot\left(K^{2} \cdot \sigma_{C \%}^{3}\right)^{j}, \\
\sigma_{C Ж}=z_{\sigma} \cdot \tau^{y 1} \cdot\left(\rho \cdot \frac{V_{C B}}{S_{\Pi}}\right)^{y}=z_{\sigma} \cdot \tau^{y 1} \cdot\left(\frac{\rho}{\rho_{C B}} \cdot \frac{m_{C B}}{S_{\Pi}}\right)^{y},
\end{gathered}
$$

де $n_{1}, n, f_{1}, f, j_{1}, j, y_{1}, y$ - показники ступеню.

Обговорення результатів. Для аналізу отриманих результатів теоретичних досліджень, використовуючи формули (12), (18)...(20), побудували графічні залежності досліджуваних властивостей структурованих сумішей від обраних для досліджень параметрів. Отримані залежності представлені на рис. 4.

3 аналізу ходу залежностей на рис. 4, а витікає, що, при інших незмінних параметрах, обсипальність будь-якої структурованої суміші зменшується з пониженням її уявної щільності, довжини випробуваного зразка і його газопроникності, а також зі збільшенням її межі міцності при стисненні. 
3 аналізу ходу залежностей на рис. 4, б витікає, що гранично-припустима стріла прогину бруса зростає (зменшується крихкість) зі зменшенням уявної щільності та збільшенням межі міцності при стисненні структурованої суміші.

3 аналізу ходу залежностей на рис. 4, в витікає, що міцність структурованої суміші підвищується зі збільшенням об'ємної частки сполучного матеріалу

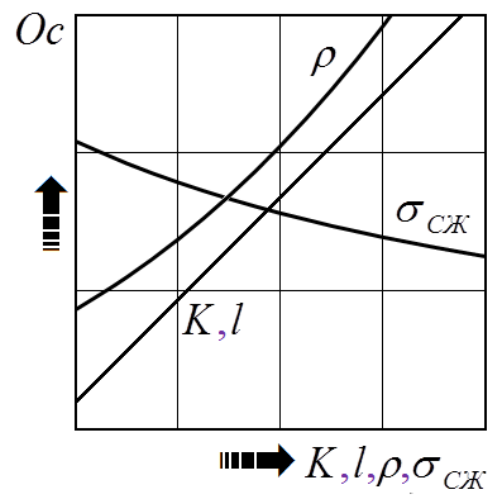

a

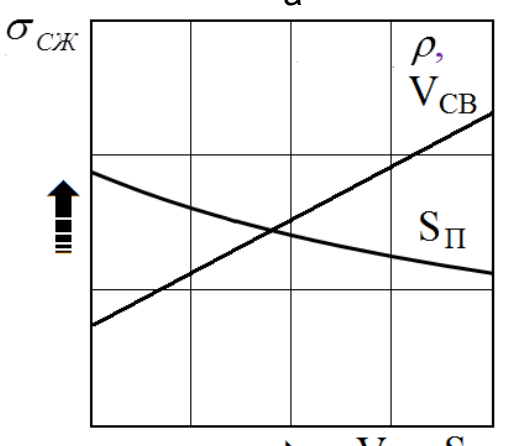

$\stackrel{\mathrm{IIM}}{\Rightarrow}, \mathrm{V}_{\mathrm{CB}}, \mathrm{S}_{\Pi}$

B в суміші і зменшенням питомої поверхні ії̈ піщинок (підвищенням фрракції піску).

3 аналізу ходу залежностей на рис. 4, г витікає, що робота вибивання стрижневої суміші з виливків зростає зі збільшенням ії залишкової межі міцності на стиск, газопроникності, питомої щільності і довжини зразка (стрижня).

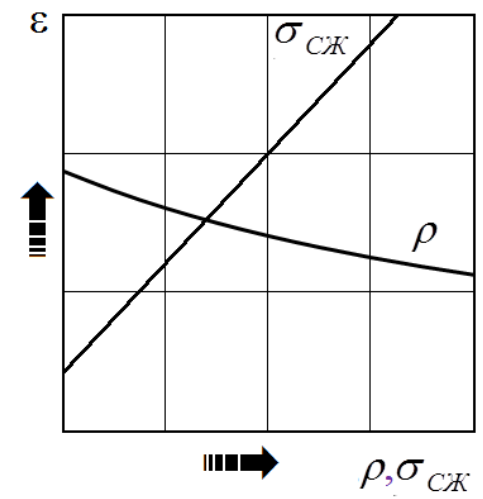

6

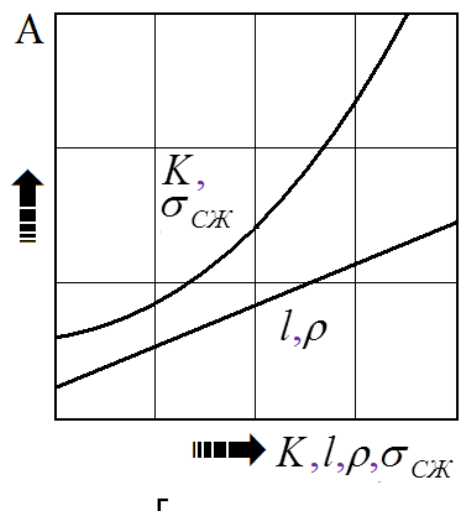

$\Gamma$

Рисунок 4 - Залежності обсипальності (а), стріли прогину (б), межі міцності при стисненні (в) і роботи вибивання (в) структурованої суміші з виливка від параметрів, що входять в фрормули (12), (18) ... (20) та (21)...(24).

Таким чином, отримані формули відображають як якісний, так і кількісний взаємозв'язок між параметрами і випробуваного тіла, і властивостями його матеріалу в прийнятих методах і методиках проведення випробувань і визначень.

Між дослідженими параметрами існує певний зв'язок. 3 цього зміна будь-якого параметра структурованої суміші неминуче призводить до відповідних змін і інших її властивостей. Крім цього, відповідно до формули (19), можна констатувати, що в першому наближенні припустимо оцінювати вибивання стрижнів за величиною залишкової міцності їх матеріалу.

Висновки. Між властивостями і параметрами структурованих сумішей, використовуваних для виготовлення ливарних фоорм і стрижнів, існують складні функціональні зв'язки. Вперше встановлені функціональні залежності між обсипальністю, кри- хкістю, міцністю, роботою вибивання виливків 3 форм і стрижнів з виливків і рядом параметрів і властивостей структурованих формувальних i стрижневих сумішей, які визначають на зразках за стандартними і загальноприйнятими методиками. Використання отриманих залежностей дозволить підвищити точність аналізу і прогнозування рівнів цих властивостей, а також прискорить процес оптимізації складів формувальних і стрижневих сумішей. Для підвищення точності прогнозування властивостей сумішей, отримані дані вимагають конкретизації в частині встановлення абсолютних величин безрозмірних констант параметричних критеріїв стосовно способу структурування сумішей і умов їх використання. Оцінку вибивання сумішей за величиною їх залишкової міцності слід розглядати, як методику першого наближення в ряду дослідженні даної властивості.

\section{Бібліографрічний опис}

1. Comprehensive modelling, analysis and optimization of furan resin-based moulding sand system with sawdust as an additive / Chate G.R. and oth. Journal of the Brazilian Society of Mechanical Sciences and Engineering. 2019. Vol 41:183. № 4. P. 1-24. DOl: 10.1007/s40430-019-1684-0. (Scopus). 
2. Selection of hardening technology of moulding sand with hydrated sodium silicate binder devoted to aluminum alloys ablation casting / Major-Gabryś K. and oth. Archives of Metallurgy and Materials. 2019. Vol. 64 (1). № 1. P. 359-364. DOI: 10.24425/amm.2019.126260. (Scopus).

3. Юрасов В.В., Сильченко Т.Ш., Кидалов Н.А. Разработка жидкостекольного связующего для смесей литейного производства из нанодиспергированных ударно-волновой обработкой щелочных силикатов натрия. Литейщик России, 2011. № 2. С. $42-46$.

4. Составы смесей, обеспечивающие высокую податливость и выбиваемость стержней / А.В. Афонаскин и др. Литейное производство, 2011. № 3. С. 8-10.

5. Использование отвалов отработанной жидкостекольной смеси при изготовлении форм / В.А. Кукарцев и др. Литейное производство, 2015. № 5. С. 6-8.

6. Свойства жидкостекольных смесей при модифицировании жидкого стекла ПАВ / Л. А. Иванова и др. Литейное производство, 2015. № 8. С. 6-9.

7. Иванова Л.А., Чернышов Е.А., Кузнецов С.А. Влияние комплексного модификатора на остаточную прочность жидкостекольных смесей. Литейное производство, 2016. № 11. С. 16-18.

8. Вспомним забытые технологии: формовочные смеси с высокой прочностью в сыром состоянии / Белобров Е. А. и др. Литье Украины, 2018. № 1. С. 27-30.

9. Вспомним забытые технологии: Еще раз о производстве отливок в сырых формах / Белобров Е.А. и др. Литье Украины, 2017. № 10. С. 18-22.

10. Жуковский С.С., Лясс А.М. Формы и стержни из холоднотвердеющих смесей. Мосвка; Машиностроение, 1976. 224 с.

11. Исследование стержневой смеси на связующей композиции Cordis-Anorgit / Финкельштейн А.Б. и др. Литье Украины, №7. С. 15-18.

12. Способ определения выбиваемости фрормовочных и стержневих смесей на образцах: А.с. 750318 CCCP: М.Кл. G01N1/00; G 01N3/32; B22C1/00. № 2569217/25-02; заявл. 06.01.1978; опубл. 23.07.1980. Бюл. №27.

13. Повышение качества отливок при литье в песчано-смоляные формы. Монография / А.З. Исагулов и др. Вена: «East West» Association for Advances Studies and Higher Education, 2015. 188 c.

14. Арифр Тапдыг оглы Мамедов, Вугар Джаваншир оглы Мамедов. Исследование физикомеханических свойств жидкостекольных теплоизоляционных смесей. Науковий вісник YKNE України, 2014. Вып 24.8. С. 145-149.

15. Сапожников М.Я., Булавин И.А. Машины и аппараты силикатной промышленности.Изд. 2-е, перераб. и доп. Москва: Промстройиздат, 1955. 424 с.

16. Батунер Л.М., Позин М.Е. Математические методы в химической техник. Л.: ГХИ, 1963. 638 с.

17. Повышение прочностных свойств сырых песчано-глинистых формовочных смесей путем электромагнитной обработки воды / Дан Л.А. и др. Вісник приазовського державного технічного університету, 2012. № 24. С. 143-147.

18. Влияние влажности и зернистости песка на основе кварца на свойства песчано-глинистой формовочной смеси / Фесенко А.Н и др. Научный вестник ДГМА, 2017. №1 (22Е). С. 104-111.

19. Рагимова К.Э. Промышленное испытание противопригарных свойств формовочных и стержневых смесей с техногенными отходами. Системные технологии, 2015. № 4(99). С. 49-55.

\section{References}

1. Comprehensive modelling, analysis and optimization of furan resin-based moulding sand system with sawdust as an additive / Chate G.R. and oth. Journal of the Brazilian Society of Mechanical Sciences and Engineering. 2019. Vol 41:183. № 4. P. 1-24. DOI: 10.1007/s40430-019-1684-0. (Scopus).

2. Selection of hardening technology of moulding sand with hydrated sodium silicate binder devoted to aluminum alloys ablation casting / Major-Gabryś K. and oth. Archives of Metallurgy and Materials. 2019. Vol. 64 (1). № 1. P. 359-364. DOI: 10.24425/amm.2019.126260. (Scopus).

3. Yurasov V.V., Sil'chenko T.SH., Kidalov N.A. Razrabotka zhidkostekol'nogo svyazuyushchego dlya smesey liteynogo proizvodstva iz nanodispergirovannykh udarno-volnovoy obrabotkoy shcheochnykh silikatov natriya. Liteyshchik Rossii, 2011. № 2. S. 42-46.

4. Sostavy smesey, obespechivayushchiye vysokuyu podatlivost' i vybivayemost' sterzhney / A.V. Afonaskin i dr. Liteynoye proizvodstvo, 2011. № 3. S. 8-10.

5. Ispol'zovaniye otvalov otrabotannoy zhidkostekol'noy smesi pri izgotovlenii form / V. A. Kukartsev i dr. Liteynoye proizvodstvo, 2015. № 5. S. 6-8.

6. Svoystva zhidkostekol'nykh smesey pri modifitsirovanii zhidkogo stekla PAV / L. A. Ivanova i dr. Liteynoye proizvodstvo, 2015. № 8. S. 6-9.

7. Ivanova L.A., Chernyshov Ye.A., Kuznetsov S.A. Vliyaniye kompleksnogo modifikatora na ostatoch uyu prochnost' zhidkostekol'nykh smesey. Liteynoye proizvodstvo, 2016. № 11. S. 16-18.

8. Vspomnim zabytyye tekhnologii: formovochnyye smesi s vysokoy prochnost'yu v syrom sostoyanii / Belobrov Ye.A. i dr. Lit'ye Ukrainy, 2018. № 1. S. 27-30. 
9. Vspomnim zabytyye tekhnologii: Yeshche raz o proizvodstve otlivok $v$ syrykh formakh / Belobrov Ye.A. i dr. Lit'ye Ukrainy, 2017. № 10. S. 18-22.

10. Zhukovskiy S.S., Lyass A.M. Formy i sterzhni iz kholodnotverdeyushchikh smesey. Mosvka; Mashinostroyeniye, 1976. $224 \mathrm{~s}$.

11. Issledovaniye sterzhnevoy smesi na svyazuyushchey kompozitsii Cordis-Anorgit / Finkel'shteyn A.B. i dr. Lit'ye Ukrainy, №7. S. 15-18.

12. Sposob opredeleniya vybivayemosti formovochnykh i sterzhnevikh smesey na obraztsakh: A.s. 750318 SSSR: M.KI. G01N1/00; G 01N3/32; B22C1/00. № 2569217/25-02; zayavl. 06.01.1978; opubl. 23.07.1980. Byul. № 27 .

13. Povysheniye kachestva otlivok pri lit'ye v peschano-smolyanyye formy. Monografiya / A.Z. Isagulov i dr. Vena: «East West» Association for Advances Studies and Higher Education, 2015. $188 \mathrm{~s}$.

14. Arif Tapdyg ogly Mamedov, Vugar Dzhavanshir ogly Mamedov. Issledovaniye fizikomekhanicheskikh svoystv zhidkostekol'nykh teploizolyatsionnykh smesey. Naukoviy vísnik YKNE Ukraîni, 2014. Vyp 24.8. S. 145-149.

15. Sapozhnikov M.YA., Bulavin I.A. Mashiny i apparaty silikatnoy promyshlennosti.lzd. 2-ye, pererab. i dop. Moskva: Promstroyizdat, 1955. 424 s.

16. Batuner L.M., Pozin M.Ye. Matematicheskiye metody v khimicheskoy tekhnik. L.: GKHI, 1963. 638 s.

17. Povysheniye prochnostnykh svoystv syrykh peschano-glinistykh formovochnykh smesey putem elektromagnitnoy obrabotki vody / Dan L.A. i dr. Vísnik priazovs'kogo derzhavnogo tekhníchnogo uníversitetu, 2012. № 24. S. 143-147.

18. Vliyaniye vlazhnosti i zernistosti peska na osnove kvartsa na svoystva peschano-glinistoy formovochnoy smesi / Fesenko A.N i dr. Nauchnyy vestnik DGMA, 2017. №1 (22E). S. 104-111.

19. Ragimova K.E. Promyshlennoye ispytaniye protivoprigarnykh svoystv formovochnykh i sterzhnevykh smesey s tekhnogennymi otkhodami. Sistemnyye tekhnologii, 2015. № 4(99). S. 49-55.

Стаття поступила 1.11.2018 